\author{
Paweł Kowalski \\ University of Warsaw - Faculty of Geography and Regional Studies - Chair of Cartography \\ 00-927 Warsaw, Krakowskie Przedmieście 30 \\ e-mail: pkowalsk@uw.edu.pl
}

\title{
CARTOGRAPHIC METHODS AND THEIR CORRECTNESS ON MAPS IN THE POLISH PRESS SINCE THE MID-19TH CENTURY
}

\begin{abstract}
On the background of the conditions of functioning of the Polish press since the mid-19th century, the paper describes cartographic and graphic methods used on press maps, with the emphasis on the quantitative methods of information presentation. The qualitative methods were mostly used in a proper way. The factors determining the level of press mapping were the skills of map makers and the limitations resulting from the letterpress printing technology. The application of computer technology and the shift to offset printing in the last decade of the $20^{\text {th }}$ century overcame these obstacles. New possibilities of the creation of maps with richer content and more graphically effective emerged. Despite these new possibilities one still needs at least basic knowledge on cartographic methods and map graphics in order to be able to prepare the cartographically correct maps. The maps presented in this paper focus on the presentation of the most common mistakes, with less emphasis put on the cartographic methods and map graphics.
\end{abstract}

Key words: history of journalistic (press) mapping, censorship, qualitative and quantitative forms of presentation, map methodical correctness.

The basic aim of maps (also press maps as their specific kind) is to present spatial information. The special character of these maps is the result of their different (compared to standard maps) function and role in the of information transfer process. Their aim is to provide timely, clear and demonstrative visual information. Press maps are designed to support and sometimes to replace printed text. The message should be visually attractive, but at the same time unambiguous 
so that it could fulfill the informative function and facilitate the process of memorizing. The aim of the press illustration is also to draw the readers' attention to issues, which might be omitted when presented in form of a pure textual information. The graphic design and features of press maps until the lest decade of the $20^{\text {th }}$ century were determined by the technological process of press printing. The letterpress technology limited the possibilities of more elaborate presentation forms. The application of computer technology as well as the shift to the offset printing allowed for the advancement of the map graphic level up to the level of traditional maps. As a result, it became possible to increase the diversity of methods and forms of presentation used on press maps and also to provide maps illustrating subjects, which were formerly difficult to map due to technical limitations. Also, it became possible to use a wide array of specialized services provided by infographic agencies and various cartographic databases. The significantly reduced timeframe required to prepare maps allows for their presentation on web sites of news portals and electronic versions of newspapers shortly after the event the map depict happen.

The current state of knowledge on the subject tells us that the first map in the Polish press in the Kurier Warszawski in 1840. The press on Polish lands, occupied since the partition of Poland, by the Austrian Empire, Russian Empire and the Kingdom of Prussia, had severely more difficult conditions of development, compared to their British, French or German counterparts. In highly industrialized, Western European countries, press was in significantly higher demand, and also press law was much more liberal, with significantly lower censorship interference. Under constant threat of financial sanctions, newspaper circulation confiscates, close downs and repressions toward the authors and editors, the editorial boards placed less emphasis on the graphic form of their newspapers. Also, illustrations severely increased the cost of publication and lengthened their preparation time. The accelerated development of the Polish press became possible only after the European Revolutions of 1848 (known in Poland as the Spring of Nations) and was a result of the press law liberation, and partial repeal of the censorship restrictions by the occupying powers. These were one of most important factors impeding the development of the press. For example, in the provincial towns of the Russian-occupied part of Poland, there were no local censorship offices, and the press was censored either in Warsaw or by the local officials, who often lacked 
adequate press law knowledge. The consent of the Warsaw Censorship Committee was required even to import new printing machines.

In the history of Polish press cartography, one can discern four periods: until Poland regained independence in 1918, the interwar period, the Polish People's Republic (PRL) and finally the period after the social and political changes in 1989, which concurred with the introduction of computer technology to the newspaper production cycle.

In the whole $19^{\text {th }}$ century and in the first two decades of the $20^{\text {th }}$ century, general reference maps with very simplified content dominated in newspapers. They most often presented location of events of the wars, especially those in which the occupying powers took part. In the years following the end of the World War I, maps more and more often referred not only to the war and conflicts, but started to give general overview of a given area or to show location of events described in articles on nautical and aeronautical accidents, natural disasters, new investments, events, crimes, acts of terror etc. The maps showing terror acts appear particularly often since the end of the $20^{\text {th }}$ century. It should be noted, that for the last 160 years, general reference and locator maps are the most often appearing kinds of press maps in both Polish and foreign press (e.g. German). On these maps, the qualitative mapping methods were most often applied, generally in a proper way, with the nominal point and areal methods used most often. However, it proved difficult to prepare maps that would be readable, and with their basic content properly exposed. Due to the time limitations, it was impossible to prepare fair copies of maps. Letterpress printing, often on inferior-quality paper made it impossible to differentiate colors by their brightness in order to show the map main and background content. Therefore, the artistic skills of map editors proved to be so valuable.

Press maps of the "pre-computer" period were of varying level of cartographic correctness. At one end of this scale, there were maps, whose graphics and accuracy of the hand drawing and lettering matched the reproduction technology of those days. At the other end, however, were the maps, pseudo-map drawings, and schemes, often drawn carelessly, too fast, significantly reduced and therefore unreadable.

As early as at the beginning of the $20^{\text {th }}$ century, first quantitative thematic maps appeared. They most often illustrated the articles written by scientists and specialists, who most often prepared the illustrations by themselves. The maps therefore reflected the level 
of cartographic knowledge of the authors of the articles themselves rather than of the map editors. Fig. 1 shows a portion of the legend of a map published in the Kurier Lwowski on November 4, 1907, with a choropleth presentation of the changes in the stock of pigs on $1 \mathrm{sq}$ $\mathrm{km}$ in the years 1903-1906. The map was prepared and published by a county veterinary doctor with the aim to justify the necessity of marking the animals with metal pierce-type earrings.

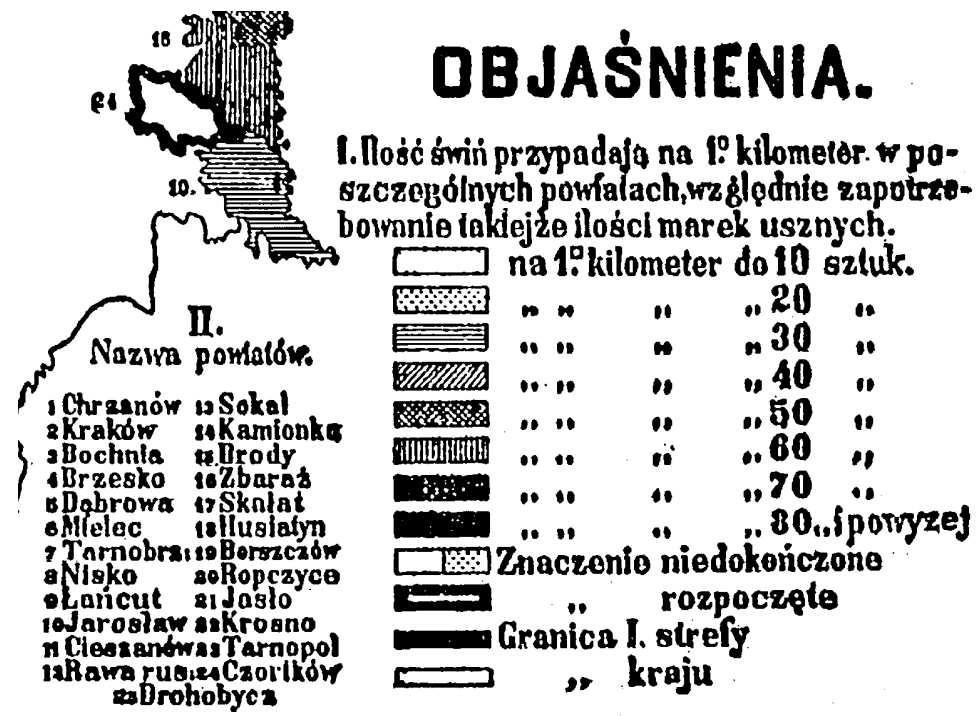

Fig. 1. A portion of a legend of a choropleth map presenting changes in the stock of pigs on $1 \mathrm{sq} \mathrm{km}$ in the years 1903-1906. (Kurier Lwowski, Nov. 4, 1907)

Another example of a quantitative method map is shown in Fig 2. This expanded illustration pertaining to the Wilno Voivodeship was an appendix to one of the popular scientific articles published in the Kurier Poznanski in 1934 and was devoted to the population issues of voivodeships. The choropleth map shows the share of national minorities in the total population of counties. The numerical values in percentages shown on the choropleth map units itself should be noted. Such a design became characteristic of press maps (as oppose to atlas maps).

After the World War II, the multi-stream development of press in Poland came to an end. After the falsified elections of 1947, the communist authorities exercised full control over the press. During the 
next decades, the press was controlled by the Polish United Workers Party (PZPR). All illustrations appearing in newspapers (pictures, maps and diagrams) were initially prepared by two agencies, and after the reorganization in 1951, by the Central Photographic Agency (CAF). The editorial boards of daily newspapers (especially those with nationwide range) employed their own drawing personnel who prepared maps and other illustrations.

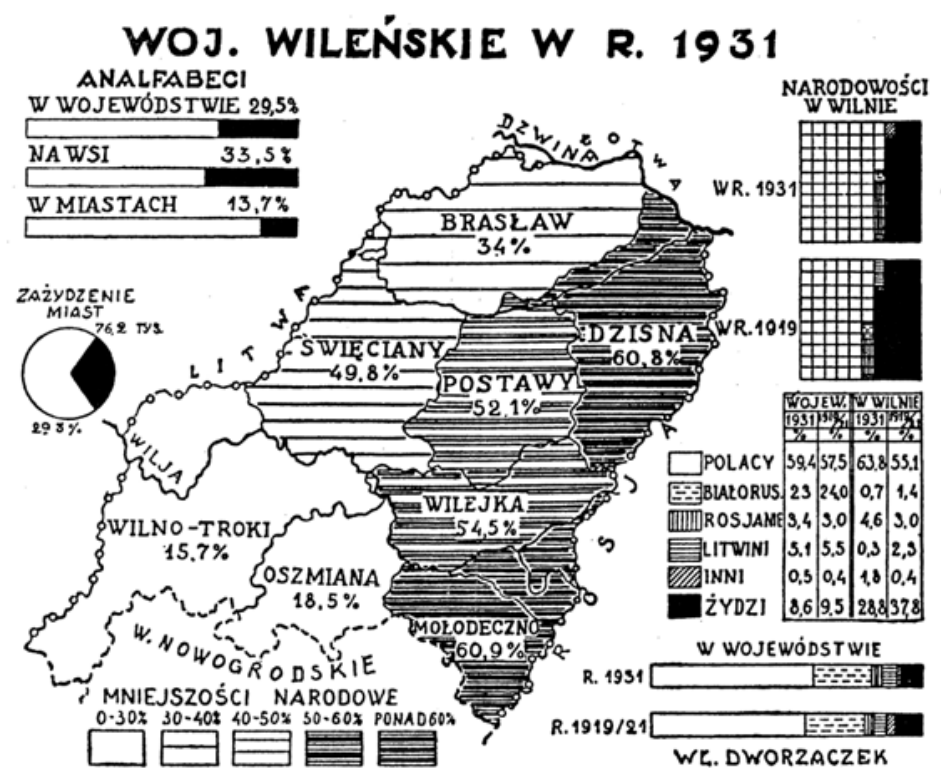

Fig. 2. Wilno Voivodeship. A choropleth map showing the share of national minorities In the total population by counties. (Kurier Poznański, Oct. 13, 1934)

As early as in the late 1940s, not only the access to information on international affairs started to be limited and censored due to the Cold War, but so was information on domestic affairs. One of the tasks of the press was to strengthen the bonds of friendship with the Soviet Union and other communist countries, hence the large number of maps showing the economic achievements of these countries published at that time. These were most often prepared centrally by the CAF for all the newspapers and their graphic level was comparatively high. However, the particular maps differed in their graphic style and diligence. 
In nationwide papers, map showing international events dominated (70 per cent of the total number of maps published in the 1960s and 1970s). These were most often general reference maps of countries described in newspaper articles and political commentaries. Also, maps showing location of natural disasters and cataclysms appeared. Another group consisted of maps locating major investments, especially those in which the communist countries participated. Qualitative forms of presentation appeared most often on propaganda maps.

A bit larger share of maps pertaining to national and local events can be noticed in the first post-war decade and also in 1970s. The goal of majority of these maps was to promote economic achievements and these were mostly general reference maps. In the 1970s, a number of transportation maps increased, mostly due to the large number of traffic restrictions caused by the new investments and reconstructions, and also during the national holidays. Their graphic design of maps in daily newspapers largely depended on their drawing, reproduction and printing technology (line cut or half-tone plate). The technology remained unchanged since the beginning of the century - hand drawing with patterns drawn directly on maps, with hand, typewriter or stencil lettering (Fig.3). Only on maps published in the largest nationwide newspapers and some of the maps prepared by the CAF agency in the mid-1970s, Letraset ${ }^{\mathrm{TM}}$ (dry transfer) lettering was used (Fig.3-Życie Warszawy, 16.06,1989). The professional map drawing technique and production technology could not have been used on press maps due to severe time limitation. Such technology was sometimes used in magazines, which allowed for a longer map preparation time (maps were often printed in color, on a higher-quality paper).

The political changes that took place after 1989, resulting in, among others, the abolition of censorship and the state mass-media monopoly, caused the transformation of press. Both the character of information and the information process itself changed. The thematic scope of maps was broadened, the number of maps largely increased, and also, due to the application of computer-aided design, the graphic level of maps gradually improved. The application of computer-aided design in the map preparation process had a profound impact on the rapid development of press mapping.

The computerization revolutionized not only the very map preparation process, their typesetting and printing, but also shortened the map preparation time. The possibilities of application of colors on press maps 

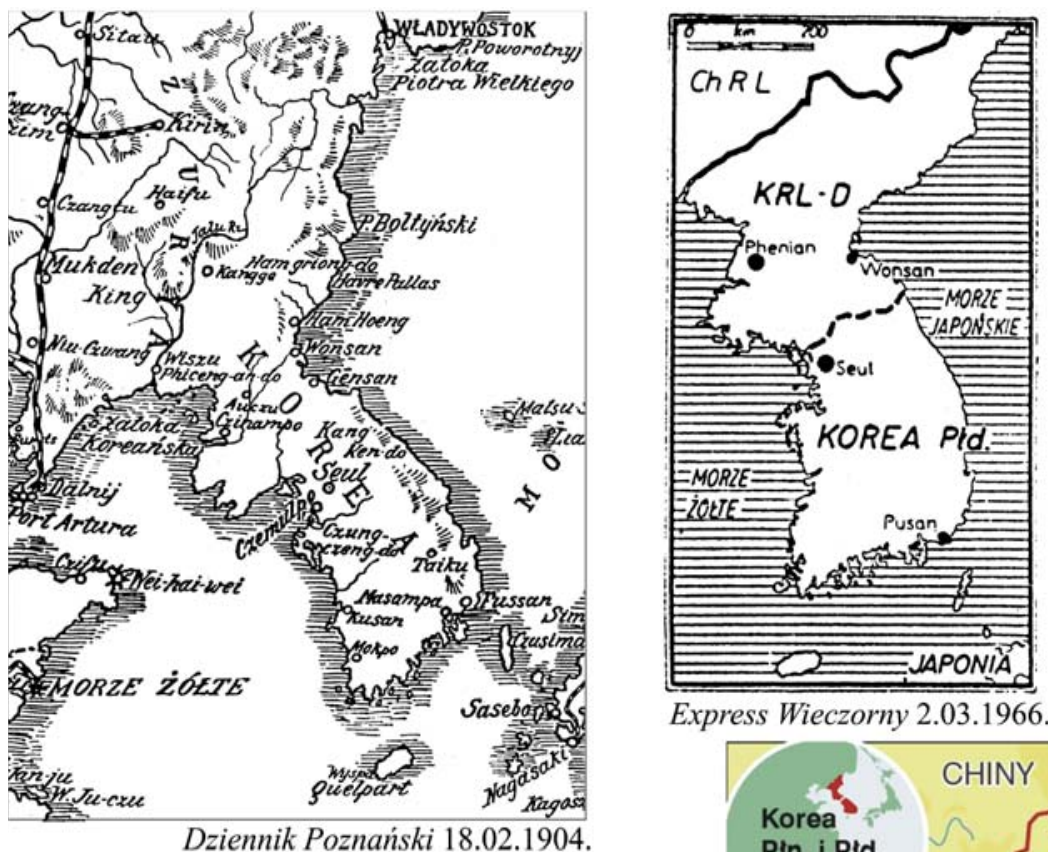

Express Wieczorny 2.03.1966.

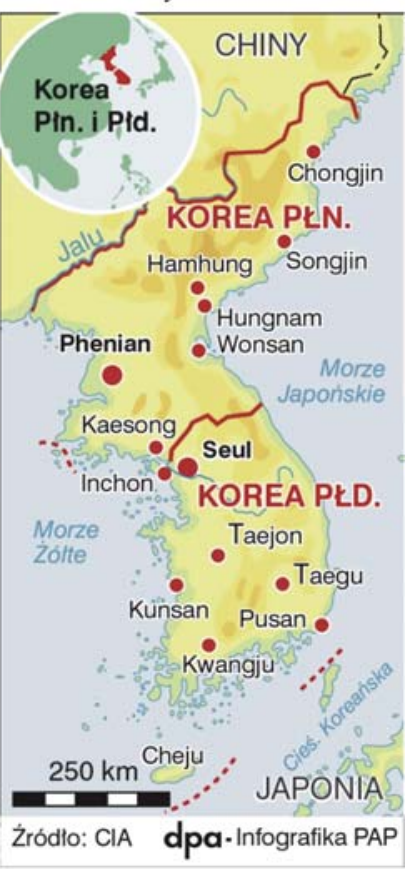

PAP 2.10.2002.

Fig. 3. Examples of different graphic design of general reference maps from the early $20^{\text {th }}$ century, from the $1960 \mathrm{~s}, 1980 \mathrm{~s}, 1990 \mathrm{~s}$ and from the early 21 st century 
largely increased. In the initial stage, these were mostly black and white maps with an additional color element overprinted, and later, full-color maps appeared more and more often. The newly adopted technology, enabled the map editors to use the services of specialized infographic agencies (Reuter, AP, AFP, Graphic News and the local Polish Press Agency (PAP) since 1997). Another result was the increasing graphic correctness of the maps prepared inside the newspapers' graphic departments. For map drawing personnel, it was not longer essential to be graphically talented. In the initial stage of the application of the new technology, there was a large demand for computer specialists (familiar with the graphic and DTP applications). Maps were often prepared by employees of various professional background, often lacking cartographic knowledge, or even worse, by people with no graphic intuition. Fascination by the multiple functions of computer-aided graphic design, they often ignored the necessity of critical evaluation of the achieved effect (Fig. 4A). The lack of readily available cartographic databases resulting in the necessity of individual map drawing in the limited timeframe, was not a favorable factor for the increased cartographic correctness. The early years of new computer technology was the period of gaining experience and creating the individual map style. It should be stressed that press maps, since their beginnings up to the present-day, were most often prepared by non-cartographers. In the history of Polish press cartography, only few map authors with professional cartographic background can be found. Nevertheless, there are numerous examples or good maps published in the daily newspapers. However, there is still a large number of incorrect (both methodically and graphically) newspaper illustrations, especially in regional and local titles.

Currently, the largest newspapers produce their own maps on local, regional and nationwide issues, whereas the map showing international affairs are most often produced by large, multinational infographic agencies. The smaller newspapers prepare their own maps dealing with local issues, and purchase the other maps from the Polish Press Agency Infographic Service, or less often from other foreign agencies. In regional newspapers published by the same publisher, maps are prepared by staff of one of the newspaper and then transferred to the other newspapers. Some of the publishers prepare their own maps showing the world and national events.

It might seem that the much broader thematic scope of press maps, together with the new possibilities of map preparation and printing 
would give an incentive to use a wider array of quantitative mapping techniques. However, this is not that case. Only on maps prepared by the Infographic Service of the Polish Press Agency, where cartographers are employed, various quantitative mapping techniques are used (choropleth maps, proportional symbol maps - circles, bars, segments and sometimes isarythmic maps).
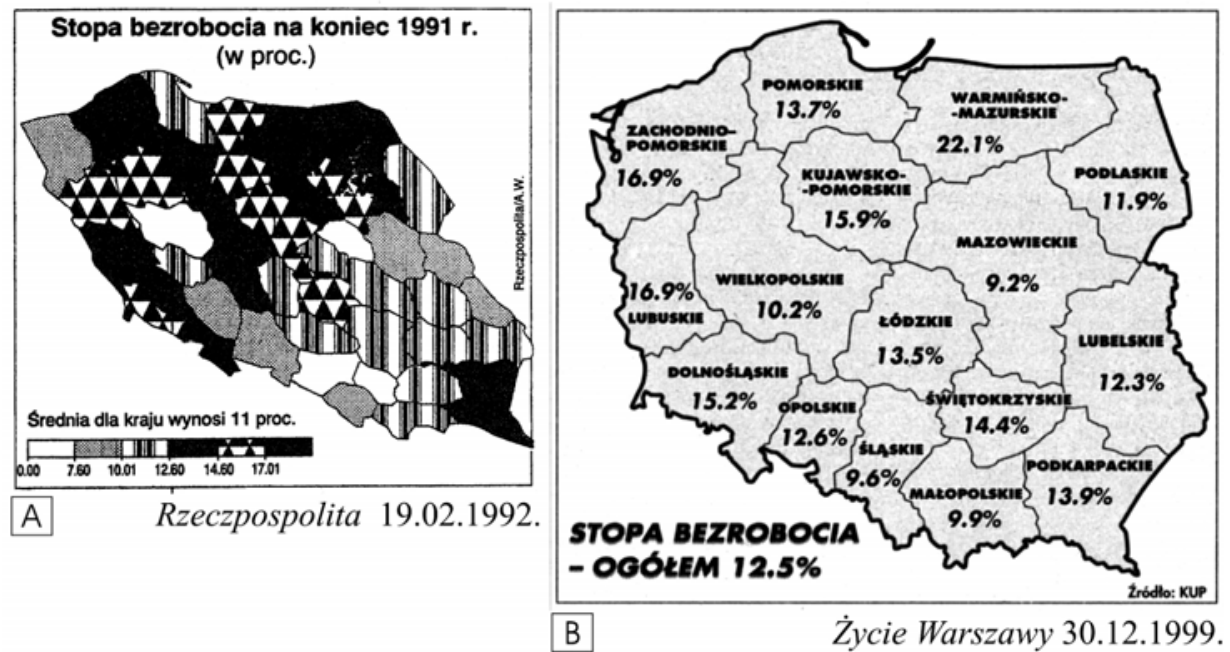

Fig. 4. An example showing uncritical fascination by the possibilities of graphic software in the early stages of computer-aided mapping (A). The choropleth map shows unemployment rate in percentage, by administrative units. A incorrect map legend should be noted. Early graphic software contained limited pattern libraries, which had to be prepared manually. Numerical values placed within the administrative units (B). Map topic: Unemployment rate in percentage, by administrative units

The editorial boards of large nationwide newspapers do not publish such methodically diversified maps. The choropleth presentation dominates, with less often used circle diagrams, and even fewer bar diagrams. There still appear maps with the numerical values denoting the values of particular mapped phenomena placed inside the administrative units (the so-called numbers on maps). These were very popular in the mid-1990s and it should be stressed that that this technique was characteristic of the early computer-aided design period (Fig 4B). Currently, such maps appear very rarely in nationwide newspapers, however comparatively more often in regional titles. 
The additional numerical value placed inside the units on choropleth maps and near or above the diagrams is a commonly used technique, which is very characteristic of journalistic maps, unlike on typical maps in atlases. Information broadened in such a way allows the map users to read them on both general and specific level. In the recent years, there is a tendency to eliminate legends in choropleth mapping, and to substitute it with the numerical values placed on the map itself. Although it is incorrect in traditional cartography, in press maps it cannot be considered as an incorrect solution. A very short reading time is characteristic of press maps. The map author should not assume that the map reader will devote their time to analyze the map legend (class selection, diagram sizes). Information must be given in a way that would allow for its quick perception. Therefore, specific information presented in the form of numerical values is given in a more general form by applying the color sequence and diagrams corresponded to particular classes.

In 1990s, on choropleth press maps, the presentation of absolute values dominated and the map legends were constructed in a way that suggested the continuous character of the mapped phenomena. Recently, the share of choropleth maps with absolute values was reduced and their legends most often show particular classes.

The possibility of application of single-tone and value color schemes resulted in the increase of maps with the correctly prepared legends. It proves much easier to illustrate the volume increase of a phenomenon using gray or color scheme than a pattern scale. Early computer choropleth presentations, often lacked the adequate selection of patterns, value or color of particular classes which resulted in the fact that the color scheme was perceived to be broken or fragmented. Now it happens significantly less often, however maps with incorrect color and value map legends still appear in press (Fig. 5). In the case of circle proportional symbols, the most common mistake is their illogical division. Instead of placing the initial division line on 12 hours (just like in a clock) it is often placed in different places (on $3,4,6,8,9$, 11 hours) and sometimes even in different places on diagrams placed next to each other, which makes their comparisons difficult (Fig 6).

The space limitation resulted in the fact that the presented examples mostly illustrate the most common drawbacks, with less emphasis on the correct application of particular mapping techniques. Formerly, the map methodical and graphic correctness was a result of the car- 


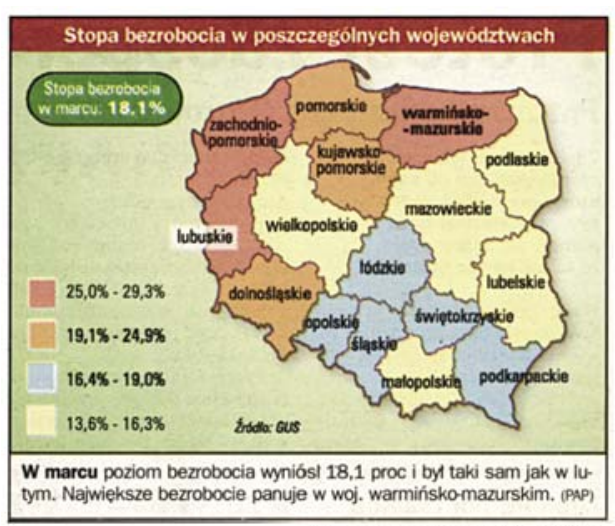

Metropol 23.04.2002.

\section{Stopa bezrobocia w Polsce}

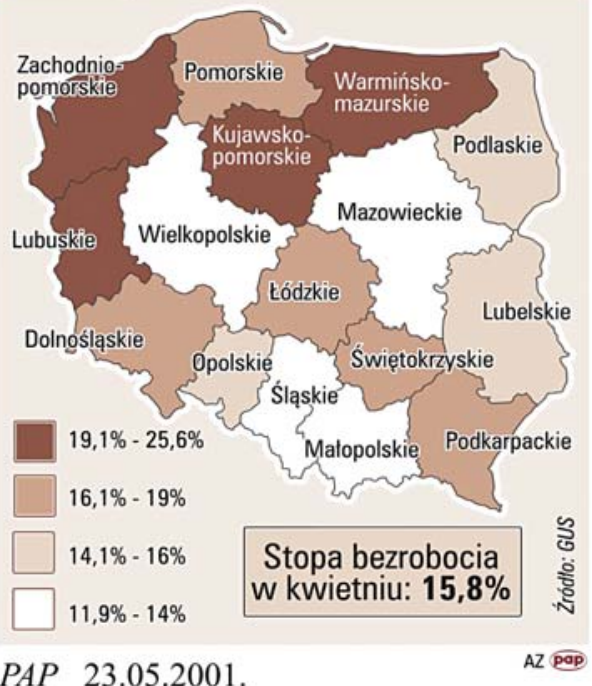

Fig. 5. Correct and incorrect color selection in the choropleth presentation of unemployment rate

\section{Procent Rosjan w wybranych krajach Europy Środkowowschodniej}

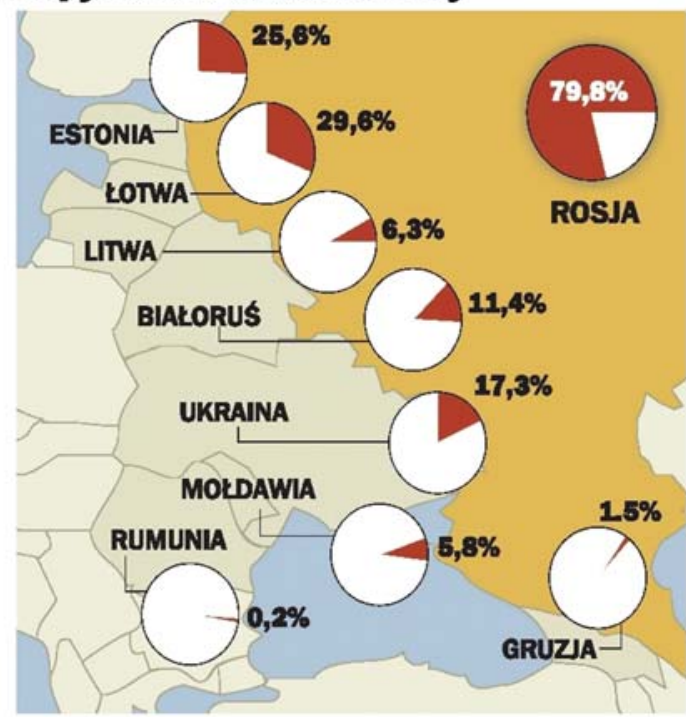

Infogrerifika: Zviad Glonti. Źródho: CIA, $2006 \mathrm{r}$.
Fig. 6. Illogical division of structural square diagrams, impeding their comparisons. (Gtos Wielkopolski, Apr. 28, 2007) 
Currently, computerized map design provided the new possibilities of map presentation, thanks to which a much broader thematic array of maps can be printed in daily newspapers. Still, in order to produce a cartographically correct map, one still needs basic knowledge on the mapping techniques and the principles of graphic design.

\section{REFERENCES}

Kowalski P., Pasławski J., 1997, Polish Journalistic Cartography in 1995. (International Conference on Mass Media Maps. Berliner Geowissenschaftliche Abhandlungen. Reihe C: Kartographie. Band 16, 229-238.

Kowalski P., 1999, Changes in press cartography in Poland over the years 19891998, The Polish Cartography 1999, Warszawa, 209-218.

Kowalski P., 2002, Mapy w polskiej prasie codziennej w latach 1918-1939, Polski Przeglad Kartograficzny, vol. 34, no 2, 115-129.

Kowalski P., 2003, Kartografia prasowa w Polsce przed uzyskaniem niepodległości w 1918 roku, Polski Przeglad Kartograficzny, vol. 35, no 1, 12-24.

Kowalski P., 2003, Kartografia prasowa w Polsce Ludowej (1945-89), Polski Przeglad Kartograficzny, vol. 35, no 2, 114-125.

Kowalski P., 2004, Development and Function of Maps in the Transmission of Press Information in Poland, Miscellanea Geographica, vol. 11, Warszawa, 209-218.

Translations by Michat Okonek 